\title{
Relational exploration of the effect of work-related scheme on job satisfaction
}

\author{
Sushmita Singh, S.K. Singh and Shashi Srivastava \\ Institute of Management, BHU, Varanasi, India
}

\begin{abstract}
Purpose - This study is an effort to explore a relationship between benefits of schemes (BoS) on the job satisfaction among handloom weavers. The weavers who are engaged in this work however face lot of challenges in terms of remuneration and working conditions. The government has been immense with various schemes that cater to the work-related problems. This paper aims to understand whether workrelated support can be a predictor for job satisfaction in this context.
\end{abstract}

Design/methodology/approach - A cross-sectional survey design was used where 335 handloom weavers randomly participated in the study. Questionnaire was administered and scale was developed and validated for the measurement of BoS by using exploratory factor analysis and confirmatory factor analysis. The effect of the benefits on the job satisfaction was investigated by using structural equation modelling on AMOS 21 platform.

Findings - The outcome suggested that the BoS significantly affects the job satisfaction and a possible predictor. This which was indicated by the value of $\mathrm{r}^{\wedge} 2$, i.e. 0.38 at significance level $p<0.001$.

Research limitations/implications - The study suggests a method for analyzing the schemes/policies in the light of the benefits that schemes intend to deliver. This would help in making suitable modifications in the schemes order to have wider outreach and large-scale inclusion of the beneficiaries.

Practical implications - The study can be useful for the policymakers to further strengthen the features of the schemes. They might work in direction of inclusion of more handloom weavers in the framework of the schemes.

Originality/value - The effects of the work-related policies on job satisfaction is still in nascent stage, so this work is all about exploration in that area.

Keywords Job satisfaction, Benefits of schemes, Handloom weaving, Labor economics,

Work-related well-being

Paper type Research paper

\section{Introduction}

Job satisfaction has its place in the labor economics as a reason for labor mobility (LévyGarboua et al., 2007). Job security is what matters to have job satisfaction. The security schemes or employment generation schemes provide a lifelong possibility for employment.

(C) Sushmita Singh, S.K Singh Singh and Shashi Singh Srivastava. Published in Vilakshan - XIMB Journal of Management. Published by Emerald Publishing Limited. This article is published under the Creative Commons Attribution (CC BY 4.0) licence. Anyone may reproduce, distribute, translate and create derivative works of this article (for both commercial and non-commercial purposes), subject to full attribution to the original publication and authors. The full terms of this licence maybe seen at http://creativecommons.org/licences/by/4.0/legalcode

The authors received no financial support for the research, authorship, and/or publication of this article.

The authors declare that there is no conflict of interest.

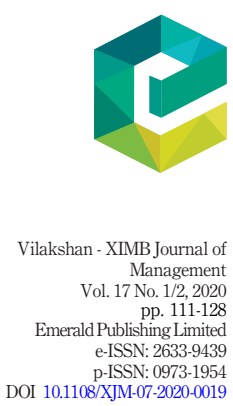


$\mathrm{XJM}$

$17,1 / 2$

The beneficiaries of such programs feel more secure about their employment and have found to be more satisfied (Origo and Pagani, 2009).The weavers who are involved in work of handloom weaving have to work in difficult working conditions such as improper lighting, poor ventilation, competition from power looms, skilled weavers quitting this profession and non-availability of easy credit facility (Report by Government of India, 2015 Ministry of Textiles "Note on Handloom Sector", Dec 2015). The work has high job demands in terms of repetitive action, long seating hours and mental attention. These conditions often are the reason for musculoskeletal disorders (Nag et al., 2010). From 1990 onwards, this sector has witnessed weavers abandoning this craft and moving to other occupations such as rickshaw driving or construction work. There were also reports of suicides and malnutrition among weavers, but the government has taken serious measures to counter the issues by providing various benefits which can help these weavers to continue to continue with this craft with dignity (Wood, 2014). Government is trying to be the support system for this sector with its various schemes and policies. The survival and sustenance of the sector is a function of job-centric support like market support, ease of credit availability, better infrastructure development for working conditions. Some important measures include enforcement of Handloom Reservation Act of 1985 to protect handloom weaving industry from competition by the power-loom industry. Implementation of various schemes such as comprehensive handloom development scheme, comprehensive handloom cluster development scheme to assist weavers with weaving-related issues of raw material supply, working conditions, up gradation of looms, skill enhancement, etc. Along with these, there have been various intervention such as celebration of National handloom day, Trade facilitation center, Promotion of India handloom Brand, Marketing Infrastructure called Handloom Haat, Common Facility Centre to provide IT-enabled services. All the support whether in form of policies or intervention have sole dedication toward upliftment of handloom weavers and making weaving a dignified occupation. The term "benefits of scheme" is abbreviated as "BoS" henceforth.

\section{Literature review}

Job satisfaction is the most extensively covered topic in Industrial/Organizational Psychology (Judge and Church, 2000). There have been several theories which pin point toward importance of job satisfaction. The major theories are such as Maslow's (1943) Hierarchy of Needs, Hertzberg's (1968) Two-Factor (Motivator-Hygiene) Theory, Adam's (1965) Equity Theory, Porter and Lawler's theory (1968) which was a modified version of Vroom's (1964) VIE Model, Locke's (1969) Discrepancy Theory, Hackman and Oldham (1976) Job Characteristics Model, Locke's (1976) Range of Affect Theory, etc. Such expansion in this domain has led to interlinking of job satisfaction with phenomena such as productivity, mental health, physical health and general well-being. It is positive state of being which is a result of one's interaction with job (Locke, 1976). Job satisfaction is measure of three constituents, i.e. emotional, cognitive and behavioral. The emotional dimension covers aspects which are specially related to job such as acknowledging the job, being excited about the job. Behavioral dimension is about how one reacts to the work like working late, trying to avoid work (Bernstein and Nash, 2008). Job satisfaction is the fulfillment and the joy that an individual gets from his or her work. There can be two flip sides of job satisfaction. One which describes how one feels about his or her work, i.e. over all feeling about the work. The second is what one feels about the particular aspect of work, i.e. the wages, working conditions, relationship with supervisor etc. (Mueller and Kim, 2008). It is how one feels toward his job specifically in terms of pay, working conditions, supervisor and colleagues, etc. Job satisfaction is the main focal 
point for discussion among organizational psychology. A happy employee is satisfied from his job. His productivity is also a result of his satisfaction from the job is all together a different arena.

Job satisfaction has its importance in labor economics too, though it is a subjective arena still it depicts the links between labor mobility. This quitting agenda was the reason for why job satisfaction could be an indicator of utility from work (Clark, 2001). When quality of work gained importance, indicators of job satisfaction were considered for assessment of employment policies in European Economy. Job satisfaction can be a measure of preferences without indicating anything about the of quality of job (Hamermesh, 2001). It all about how the workers mentally map their jobs in objective and subjective features. Studies have been conducted which focus on determinants of job satisfaction, in extension with economists' methods (Weir, 1977). Well-being theory suggests that emotions can be named as per their presence on the two orthogonal dimension one is representative of pleasure or displeasure experience, other represents the degree of arousal (Russell, 2003; Warr, 1990, 2007). Inside this two dimensional framework, well-being aspects are placed along two axes, i.e. "Depression to Enthusiasm" ("displeasure and low arousal" and "pleasure and high arousal) and "Anxiety to Comfort" ("displeasure and high arousal" and "high pleasure and low arousal”). On this framework, job satisfaction lies on pleasure dimension (Warr, 2007). Job satisfaction forms an important component of work-related well-being (Rothmann, 2008). These well-being indicators can be basis for empirical welfare and policy analysis in the labor market. There have been evidences that intrinsic satisfaction predicts overall job satisfaction better in countries where there are higher levels of welfare safety, and that extrinsic satisfaction affects the overall job satisfaction more in countries with lower levels of welfare safety (Westover, 2012). The happiness as a measure of well-being is very well considered by economists and policymakers (Helliwell et al., 2012). The welfare schemes enhance the well-being of the beneficiaries and well-being, and welfare policies are closely knitted (Heins and Deeming, 2015). Countries where there are higher welfare state provisions have reported a greater perceived job satisfaction (Westover, 2012). There has been positive relationship between welfare schemes facilities and job satisfaction as seen among the workers in apparel industry of Sri Lanka (Almeida and Perera, 2015). Sustainability measures such as Fair trade practices improves wages and working conditions of workers of cocoa plantation ion Cote d'Ivoire (West Africa). Those workers which under the ambit of cooperatives which follow fair trade practices get other benefits too (Meemken et al., 2019). The government initiated apprenticeship training programs have helped in increasing job satisfaction and overall performance and productivity of artisans in Ibadan, Oyo State (Olubisi, 2018). The infrastructure support impacts productivity positively. The handloom clusters which have access to electricity have shown better productivity in handloom clusters of rural Ethiopia (Zhang et al., 2011). The literature illustrates that the measures which affect work-related issues positively impact job satisfaction.

\section{Context of study}

Handloom sector in India is one such area where the workers are highly skilled and more than often they possess this art as legacy from previous generations. Ideally, they should be satisfied with their work because of the mastery they have in their hand weaving skills. But there have been reports of weavers' mobility from this sector owing to poor working conditions, poor wages, lack of market awareness, irregular supply of raw materials, etc. 
$\mathrm{XJM}$

$17,1 / 2$

Goswami and Jain (2014). Clearly, it shows dissatisfaction from work facets. Here in this study, the researcher wants to find out the relationship between the benefits of the government schemes and job satisfaction among handloom weavers. The government in form of different schemes has worked for upliftment of weavers, betterment of their livelihood, and work-related support has been the prime motive (Report of GoI , Ministry of Textiles Office of the Development Commissioner for Handlooms, May 2017). The handloom weaving is an eco-friendly production wherein the entire work is done by hands; there is no emission of harmful gases. The intricacies of the design are unmatched which speaks volumes about the skillset possessed by the weavers (Report by Government of India, Ministry of Textiles "Note on Handloom Sector", Dec 2015). The schemes implemented by the government focuses on these problem areas and benefits associated with schemes are inclined toward work-related aspects. One such scheme is comprehensive handloom cluster development scheme (Mega Cluster scheme) which is being implemented by the Ministry of Textiles, Government of India. The main focus areas are listed below.

The major objectives are as follows:

- to empower weavers by providing them assistance in making competitive and diversified products;

- to help weavers to avail services such as procurement, production, marketing and other support activities;

- promote design innovation and development by involvement of professional designers;

- promotion of marketing chains;

- to provide support of adequate technical infrastructure such as work-sheds, lighting facilities, treatment plants, dye houses etc.;

- to promote healthy and empowered environment where weavers also have a chance of participative decision-making; and

- to energize union of schematic help and bolster administrations from different plans and projects of different government and different organizations in the bunch to upgrade asset usage for advancement of the business, personal satisfaction of handloom falters and increment pay dimension of the weavers.

The present study tries to study the benefits that this scheme provides and up-to what extent it affects job satisfaction. Considering the fact that schemes or policies enhance wellbeing of the beneficiaries and job satisfaction being the positive predictor of work-related well-being (Rothmann, 2008), the effect of BoS on job satisfaction is being studied here. The scheme targets all the work-related issues which are posing challenges to handloom weavers which points toward some positive effects of these benefits on the job satisfaction among weavers. The study takes its base of job satisfaction from Herzberg's two factor theory from which intrinsic and extrinsic job satisfaction stems out. In the light of this, the study tries to move in the direction of finding out effects of BoS on job satisfaction.

\section{Need for study}

The handloom weavers often find themselves entangled in a viscous cycle of problems, most of which are work related. The constraints are lack of proper market information, obsolete looms, inadequate yarn supply, low wages, poor working conditions, dependency on middle men and lack of financial support (Study Report on Problems and prospects of Handloom Sector by Bankers Institute of Rural Development Lucknow, 2016). The plight had pushed 
them to almost the periphery of the social strata. There were often reports of suicide, as they were not able to repay the loans that they had taken from the master weavers. The handloom sector has also witnessed weavers' mobility and their inclination toward other jobs such as vegetable selling, rickshaw pulling, etc. (Tanusree, 2015). The government has played a significant role in the support and survival of handloom sector with the help of schemes and interventions. The schemes are designed to remove the bottlenecks in the preproduction, production and post production of the handloom weaving. Chanderi handloom cluster (Madhya Pradesh), which was declining in the earlier decade, has demonstrated striking accomplishment in the recent past (Ramswamy and Kumar (2013). The welfare regimes which foster work or employment have a positive impact on job satisfaction by improving working conditions and creating a better work life balance (Fasang et al., 2012). The active labor market policies diminish the scars of unemployment (Delhey and Kohler, 2006). The labor welfare measures in small-scale industries do carve a positive impact on job satisfaction among the workers, as depicted by a study conducted in Dehradun (Chaubey and Rawat, 2016). Job satisfaction is a component of work-related well-being. (Rothmann, 2008), and well-being indicator can be used as welfare and policy analysis in the labor market. Therefore, the arguments given above paves a way for analyzing the scheme and measuring its effect on the job satisfaction. So taking the above representations as the base, it becomes important to study the comprehensive handloom cluster development scheme from the job satisfaction perspective of weavers, as the scheme intends to deliver benefits which are work centric.

\section{Research methodology}

\subsection{Development of hypotheses}

The idea behind the work undertaken roots to application job satisfaction as variable in for labor market analysis (Freeman, 1977).Work-related well-being is found to be having its usefulness in labor economics (Green, 2010); it might be useful to study the well-being at work place as the major components include job satisfaction, occupational stress, burn out and work engagement (Rothmann, 2008). Studies have suggested that policies can be seen as positive predictors of well-being such as Housing Policy enhance well-being among the people residing in public housing in Ahmedabad (Vaid, 2013). This study gives policymakers an insight about the planning done and necessary interventions to be undertaken. Similarly, active labor market policies (ALMP) enhance subjective well-being suggesting well-being as a dimension for policy measurement. Unemployed has negative psychosocial effects. ALMP are the programs that help in employment assistance, conducting training for the skill enhancement and qualification improvement. It also includes some job creation schemes, therefore helping to address unemployment (Sage, 2015). This work is based on theory that people who are unemployed have a low subjective well-being (Murphy and Athanasou, 1999). When we look at the comprehensive handloom cluster development scheme, it mainly addresses all the issues related to work of handloom weaving. By providing all sorts of assistance right from procurement of raw material, skill enhancement, to market development. In the process of doing this, this scheme helps in better remuneration to the weavers for their work. As few reports suggested that weavers were forced to leave this work. This mobility was owing to poor wages, harsh working conditions, lack of market knowledge, irregular raw material supply. Mobility is explained by lack of job satisfaction among workers (Green, 2010), and job satisfaction is positive predictor of work-related well-being; in the light of these two findings, the present study positions its base on effects of BoS on job satisfaction: 
$\mathrm{XJM}$

$17,1 / 2$
HO. There is significant relationship between $\mathrm{BoS}$ and job satisfaction among handloom weavers (Figure 1).

H1. There is no significant relationship between BoS and job satisfaction among handloom weavers.

\section{6}

\subsection{Method}

5.2.1 Participants and procedures. The study was conducted in Varanasi. The weavers who were registered and were beneficiaries of the scheme were approached for the survey. The researcher approached 367 weavers randomly, 335 weavers agreed to be the part of study. The questionnaire was divided into two parts; first part comprised questions related to demographics. Second part had questions about BoS and Job satisfaction. The responses on rated on Likert's five-point scale. The responses on rated on Likert's five-point scale. Out of 335 weavers, 90 weavers were higher secondary pass, $(26.86 \%), 150$ weavers had studied below class 10 th $(44.77 \%)$, 85 weavers were senior secondary pass $(25.37 \%)$ and 10 weavers were graduates $(2.98 \%)$. All the handloom weavers were males who participated in the survey.

5.2.2 Measures used. The BoS was measured by using self-designed questionnaire and was rated on Likert's five point scale, i.e. 1- Strongly Disagree, 2 - Disagree, 3 - Don't Know, 4 - Agree, 5 - Strongly Agree. The researcher developed and validated 17 item scale which had 4 dimensions. For the development of questionnaire, the steps followed were analyzing content domain, item generation, judgment, calculation of content validity ration followed by exploratory factor analysis and confirmatory factor analysis. The detailed report for the Comprehensive Cluster Development Scheme was studied for content study and item generation of the instrument. In the report, certain objectives were underlined which the scheme intended to achieve. The objectives were mentioned under different heads such as Technology up-gradation, Product Diversification, Raw Material Bank, Skill Development, Marketing assistance, etc. The constructs were identified from these headings. The BoS were then transformed into statements which could be measured. For any concept to be operationalized, the constructs need to be converted into statements which can be measured (Heppner et al., 2016). Content Validity refers to the extent to which the instrument represents the construct that it intends to measure (Rusticus, 2014). Judgment stage involved confirmation of the items by the experts working in this domain. Two officials from the office of the Development Commissioner (handlooms), one cluster development executive, one Implementing agency officials, two individual handloom weavers (beneficiaries of the scheme) were contacted for this purpose. The experts were then asked to rate the items of the instrument as was asked to give a score of 1 to 3 to each item where 1 was for essential, 2 for useful but not essential and 3 for not necessary. The formula

Figure 1.

Hypothesized model of relationship between BoS and job satisfaction

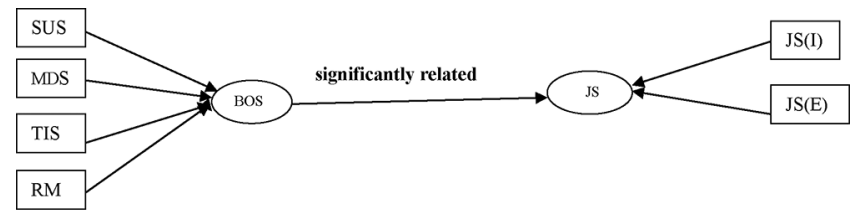

Notes: This hypothesized model is the representative of null hypothesis that BoS will significantly affect job satisfaction among handloom weavers 
for calculation of content validity ratio $(C V R)=(\mathrm{Ne}-\mathrm{N} / 2) /(\mathrm{N} / 2)$ in which $\mathrm{Ne}$ is the number of panelists indicating "essential" and $\mathrm{N}$ is the total number of panelists. The numeric value of CVR ranges from -1 to 1 (Lawshe, 1975). High scores of CVR demonstrates the agreement among the experts on the necessity of the inclusion of an item in the instrument (Ayre and Scally, 2014). The values of CVR and CVI for the instrument was calculated. The values were compared with the critical values recomputed in the Lawshe's CVR table. The value of CVI for the instrument should not be less than 0.78 . The value of CVR for each item should between 0 to 1 which indicates that more than half of the panelist found the item to be Job
satisfaction essential for the inclusion in the measuring scale (Shrotryia and Dhanda, 2019). The value of CVI for the measuring scale was found to be 0.905 , and the values for CVR for each item was between 0 to 1 (Table 1 ). There were initially 21 items, which were then reduced to 17 items after exploratory factor analysis items used to measure the benefits of the scheme:

(1) Defects in weaving has reduced.

(2) Efficiency has increased.

(3) Increase in ability to produce/weave new/ intricate designs and adopt new technology.

(4) Value addition in the designs in form of new motifs and patterns.

(5) Able to convert paper designs into fabrics/end products.

(6) Number of marketing events such as Buyer Seller Meets, Exhibitions, etc. has increased awareness about handloom products.

\begin{tabular}{lccccccc}
\hline & Expert 1 & Expert 2 & Expert 3 & Expert 4 & Expert 5 & Expert 6 & CVR \\
\hline Item 1 & $\mathrm{x}$ & $\mathrm{x}$ & $\mathrm{x}$ & $\mathrm{x}$ & $\mathrm{x}$ & $\mathrm{x}$ & 1 \\
Item 2 & $\mathrm{x}$ & $\mathrm{x}$ & $\mathrm{x}$ & $\mathrm{x}$ & $\mathrm{x}$ & 0.667 & \\
Item 3 & $\mathrm{x}$ & $\mathrm{x}$ & $\mathrm{x}$ & $\mathrm{x}$ & $\mathrm{x}$ & $\mathrm{x}$ & 1 \\
Item 4 & $\mathrm{x}$ & $\mathrm{x}$ & $\mathrm{x}$ & $\mathrm{x}$ & $\mathrm{x}$ & 0.667 & \\
Item 5 & $\mathrm{x}$ & $\mathrm{x}$ & $\mathrm{x}$ & $\mathrm{x}$ & $\mathrm{x}$ & $\mathrm{x}$ & 1 \\
Item 6 & $\mathrm{x}$ & $\mathrm{x}$ & $\mathrm{x}$ & $\mathrm{x}$ & $\mathrm{x}$ & $\mathrm{x}$ & 1 \\
Item 7 & $\mathrm{x}$ & $\mathrm{x}$ & $\mathrm{x}$ & $\mathrm{x}$ & $\mathrm{x}$ & $\mathrm{x}$ & 1 \\
Item 8 & $\mathrm{x}$ & $\mathrm{x}$ & $\mathrm{x}$ & $\mathrm{x}$ & $\mathrm{x}$ & $\mathrm{x}$ & 1 \\
Item 9 & $\mathrm{x}$ & $\mathrm{x}$ & $\mathrm{x}$ & $\mathrm{x}$ & $\mathrm{x}$ & $\mathrm{x}$ & 1 \\
Item 10 & $\mathrm{x}$ & $\mathrm{x}$ & $\mathrm{x}$ & $\mathrm{x}$ & $\mathrm{x}$ & $\mathrm{x}$ & 1 \\
Item 11 & $\mathrm{x}$ & $\mathrm{x}$ & $\mathrm{x}$ & $\mathrm{x}$ & $\mathrm{x}$ & $\mathrm{x}$ & 1 \\
Item 12 & $\mathrm{x}$ & $\mathrm{x}$ & $\mathrm{x}$ & $\mathrm{x}$ & $\mathrm{x}$ & $\mathrm{x}$ & 1 \\
Item 13 & $\mathrm{x}$ & $\mathrm{x}$ & $\mathrm{x}$ & $\mathrm{x}$ & $\mathrm{x}$ & $\mathrm{x}$ & 1 \\
Item 14 & $\mathrm{x}$ & $\mathrm{x}$ & $\mathrm{x}$ & $\mathrm{x}$ & $\mathrm{x}$ & $\mathrm{x}$ & 1 \\
Item 15 & $\mathrm{x}$ & $\mathrm{x}$ & $\mathrm{x}$ & $\mathrm{x}$ & $\mathrm{x}$ & $\mathrm{x}$ & 1 \\
Item 16 & $\mathrm{x}$ & $\mathrm{x}$ & $\mathrm{x}$ & $\mathrm{x}$ & $\mathrm{x}$ & 0.667 & \\
Item 17 & $\mathrm{x}$ & $\mathrm{x}$ & $\mathrm{x}$ & $\mathrm{x}$ & $\mathrm{x}$ & $\mathrm{x}$ & 1 \\
Item 18 & $\mathrm{x}$ & $\mathrm{x}$ & $\mathrm{x}$ & $\mathrm{x}$ & $\mathrm{x}$ & 0.667 & \\
Item 19 & $\mathrm{x}$ & $\mathrm{x}$ & $\mathrm{x}$ & $\mathrm{x}$ & $\mathrm{x}$ & $\mathrm{x}$ & 1 \\
Item 20 & $\mathrm{x}$ & $\mathrm{x}$ & $\mathrm{x}$ & $\mathrm{x}$ & $\mathrm{x}$ & 0.667 &
\end{tabular}


$\mathrm{XJM}$

$17,1 / 2$

118

(7) Marketing events has given you opportunity to directly sell your products and get better remuneration

(8) Development and hosting of website, e commerce, market intelligence/survey, etc. has made you aware about market trends.

(9) Work-shed creation has made my workplace a better place to work.

(10) Lighting facility has made my workplace a better place to work.

(11) Financial assistance for loom up-gradation has helped in reducing drudgery.

(12) Upgraded loom has improved productivity.

(13) Upgraded loom has improved quality.

(14) Effluent treatment plant has reduced pollution hazards

(15) Development and hosting of website, e commerce, market intelligence/survey, etc. has made you aware about market trends.

(16) Number of marketing events such as Buyer Seller Meets, Exhibitions, etc. has increased awareness about handloom products.

(17) Marketing events has given you opportunity to directly sell your products and get better remuneration.

The table includes the items which were used to study about the benefits of the scheme. These items were generated after considering the reports of Textile Ministry, Government of India and literature about handloom industry .

Similarly, scale was used for measuring job satisfaction among the weavers based on extrinsic and intrinsic job satisfaction dimensions. The items in the scale consisted items adopted from The Minnesota Job Satisfaction Questionnaire (MSQ) (Weiss et al., 1967).The items of the scale were modified as per the context of the study. Job satisfaction comprises two parameters, namely, extrinsic and intrinsic. Intrinsic job satisfaction reflects ones feeling about the nature of the job, whereas extrinsic job satisfaction is about how one feels facets of the job, i.e. conditions external to the job (Hirschfeld, 2000). To generate items for questionnaire focus group discussion, semi structured interviews and officials from handloom office (Varanasi) were consulted. Thereafter items were generated; previously developed scales were also studied for the purpose. Initially, 16 items were developed which, out of which 11 were retained after exploratory factor analysis items used to measure the job satisfaction:

(1) There is proper working condition such as work-sheds (working condition).

(2) There is proper lighting arrangement\& ventilation (working condition).

(3) I get all the facilities at my workplace itself to facilitate weaving activity(Cluster support).

(4) The job gives me trust that my job is secure (job security).

(5) My job provides for steady employment(job security).

(6) My pay is sufficient to meet my ends (wages).

(7) The praise I get for doing a good job (recognition).

(8) The feeling of accomplishment I get from the job (achievement).

(9) The designs which have been made by me is liked by the supervisor (Recognition).

(10) Being able to myself keep busy all the time (work Itself).

(11) I get chance to utilize my skills(skill utilization). 
The table includes the items to study job satisfaction . These items were adopted from The MSQ (Weiss et al., 1967). Contextual modification was done.

The factors having values of factor loadings less than 0.5 were removed.

5.2.2.1 Exploratory factor analysis. For factor extraction, principal component analysis was performed on both the scale items Appropriateness of the factor analytic model was depicted by correlation matrix. The value of Kaiser-Meyer-Olkin (KMO) measure of sampling adequacy gave idea whether data is suitable for factor analysis or not. The value of Bartlett's test of sphericity tells the data reduction technique is actually useful measure to compress the data. The value KMO Measure of Sampling Adequacy should be above the acceptable value, i.e. 0.6 , which indicates that the size of the sample taken was proportionate with the scale used (Madanchian et al., 2018). The value of Bartlett's test of sphericity was also large enough for factor analysis. (Tables 2 and 3). The KMO value for job satisfaction scale was 0.763 and 0.659 for BoS scale.

Two factors structure emerged for job satisfaction which were named extrinsic and intrinsic job satisfaction. The factors were in congruence with the literature. Similarly four factor structure resulted for BoS scale, which was resonating with literature and reports consulted (Tables 4 and 5).

There were four factors which combined to form BoS (Table 5). All the values of factor loading were above 0.5. Factor 1-5 were named as Skill upgradation support, 6-11 were named as Technical Infrastructure Support, 12-14 were called as Raw material support and Factor 15-17 were named as market development support. The factors thus obtained were resonating with the objectives and features mentioned in the guidelines of the scheme ((Report of GoI, 2017, Ministry of Textiles Office of the Development Commissioner for Handlooms, May 2017).

Two factors emerged which combined to form Job satisfaction (Table 4). All the values of factor loading were above 0.5 . Factor $1-6$ were named Extrinsic Job satisfaction and 7-11

Kaiser-Meyer-Olkin measure of sampling adequacy

Bartlett's Test of Sphericity

Approx. chi-square

1635.619

df

Sig.

Note: The table reflects the value of KMO and Bartlett's Test of sphericity to give an idea whether sample considered is adequate or not

Source: Computed by researcher

Job
satisfaction

119

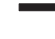




\begin{tabular}{|c|c|c|}
\hline & \multicolumn{2}{|c|}{ Component } \\
\hline & & 2 \\
\hline 1. There is proper working condition such as work-sheds(working condition) & 0.845 & \\
\hline 2. There is proper lighting arrangement\& ventilation(working condition) & 0.813 & \\
\hline 3. I get all the facilities at my workplace itself to facilitate weaving activity(Cluster support) & 0.790 & \\
\hline 4. The job gives me trust that my job is secure.(Job security) & 0.768 & \\
\hline 5. My job provides for steady employment. .(Job security) & 0.762 & \\
\hline 6. My pay is sufficient to meet my ends.(Wages) & 0.752 & \\
\hline 7. The praise I get for doing a good job.(Recognition) & & 0.788 \\
\hline 8. The feeling of accomplishment I get from the job.(achievement) & & 0.725 \\
\hline 9. The designs which have been made by me is liked by the supervisor.(Recognition) & & 0.721 \\
\hline 10. Being able to myself keep busy all the time(Work Itself) & & 0.693 \\
\hline 11. I get chance to utilize my skills .(skill utilization) & & 0.648 \\
\hline
\end{tabular}

Table 4.

Result of rotated component matrix for job satisfaction
Notes: The table gives the total number of factors for job satisfaction which emerge after principal component analysis. Here, there are two factors that comes out after PCA. Factor 1-6 are extrinsic factors and $7-11$ are intrinsic factors

Source: Computed by researcher

\section{Table 5.}

Result of rotated component matrix for $\mathrm{BoS}$

\begin{tabular}{|c|c|c|c|c|}
\hline & \multicolumn{3}{|c|}{ Component } & \multirow[b]{2}{*}{4} \\
\hline & 1 & 2 & 3 & \\
\hline 1. You are able to convert paper designs into fabrics/end products. & 0.927 & & & \\
\hline 2. Increase in Ability to weave new designs and adopt new technology & 0.894 & & & \\
\hline 3. Efficiency has increased & 0.885 & & & \\
\hline 4. Defects in weaving has reduced & 0.871 & & & \\
\hline 5. There is Value addition in terms of designs of new motifs \& patterns & 0.869 & & & \\
\hline 6. Lighting facility has made my workplace a better place to work & & 0.844 & & \\
\hline 7. Effluent treatment plant has reduced pollution hazards & & 0.843 & & \\
\hline 8. Work-shed creation has made my workplace a better place to work & & 0.815 & & \\
\hline 9. Upgraded loom has improved quality & & 0.786 & & \\
\hline 10. Loom up-gradation has helped in reducing drudgery & & 0.646 & & \\
\hline 11. Upgraded loom has improved productivity & & 0.540 & & \\
\hline 12. Regular supply of yarn has made production easier & & & 0.854 & \\
\hline 13. Good quality of yarn helps in making better quality products & & & 0.818 & \\
\hline 14. Timely supply of yarn & & & 0.782 & \\
\hline $\begin{array}{l}\text { 15. Development and hosting of website, e commerce, market intelligence/ } \\
\text { survey etc. has made you aware about market trends }\end{array}$ & & & & 0.7 \\
\hline $\begin{array}{l}\text { 16. Number of marketing events such as Buyer Seller Meets, Exhibitions etc. } \\
\text { has increased awareness about handloom products }\end{array}$ & & & & 0.749 \\
\hline $\begin{array}{l}\text { 17. Marketing events has given you opportunity to directly sell your products } \\
\text { and get better remuneration }\end{array}$ & & & & 0.74 \\
\hline
\end{tabular}

Notes: The table gives the total number of factors for BoS which emerge after principal component analysis. Here there are four factors that comes out after PCA

Source: Computed by researcher

were named as Intrinsic Job Satisfaction. Items 1,2,3 and 9 were self-designed questions and items 4,5,6,7,8,10,11 were adopted from MSQ. These factor loadings were in congruence with the literature which suggests that two factor model for job satisfaction is appropriate (Hirschfeld, 2000). For internal consistency, Cronbach's alpha coefficient was calculated for 
both the scales, which was above the threshold value i.e.0.7. The values were: Job satisfaction scale- 0.788 and $\mathrm{BoS}$ (BoS) scale -0.859 .

5.2.2.2 Confirmatory factor analysis. The factors that were retained from exploratory factor analysis were confirmed using confirmatory factor analysis on AMOS 20. This gave a fair idea about the psychometric properties of the measuring instruments used as well as the construct validity. The content validity was established using content validity ratio and content validity index after consultation with the experts and officials from handloom DC office. The discriminant validity and convergent validity were obtained for both the measuring instruments developed. The values of composite reliability (CR), average variance extracted (AVE), measure share variance (MSV), average shared variance (ASV) were all within standard range. CR was greater than AVE in this particular study. For establishing discriminant validity, AVE $>$ MSV and AVE $>$ ASV should hold true (Cohen et al., 2005), which was the case in this context (Tables 6 and 7)). To establish convergent validity, the value of AVE should be more than 0.5 (Soleimani et al., 2016). The values of AVE were above 0.5 for both the measuring instruments (Tables 6 and 7). Thus both the measuring used were found to be valid and reliable.

5.2.2.3 Structural model specifying relationship between benefits of schemes and job satisfaction. After the confirming and validating the measuring scale used, the relationship between the BoS and job satisfaction was studied using by structural equation modelling (Figure 2). The indices used to test the fit of the model were goodness-of-fit index (GFI), adjusted GFI (AGFI) and Root Mean Square Error of Approximation (RMSEA), CMIN/DF, Comparative Fit Index (CFI) and Normed Fit Indices (NFI). The RMSEA is a measure of how well the model with particular dimensions fits the populations covariance matrix (Byrne, 2013). The value of RMSEA between 0.08 and 0.10 suggests a mediocre fit, and the value below 0.08 shows a good fit (MacCallum et al., 1996). The accepted values of AGFI, GFI, CFI and NFI should be greater than or equal to 0.90. to have a good fit (Chen, 2008). The values, as depicted in Table 8, were all within the given standard range. The relationship among the variables, i.e. dependent and independent variables, were found to be significant

\begin{tabular}{lcccc}
\hline Constructs & CR & AVE & MSV & ASV \\
\hline Skill up gradation support & 0.944 & 0.791 & 0.152 & 0.090 \\
Technical Infrastructure support & 0.885 & 0.569 & 0.152 & 0.094 \\
Raw material support & 0.858 & 0.669 & 0.081 & 0.027 \\
Market development support & 0.800 & 0.572 & 0.136 & 0.144
\end{tabular}

Note: The table gives the results for convergent validity and discriminant validity with the help of confirmatory factor analysis(CFA) on AMOS 21 platform

Source: Computed by researcher

\section{Job satisfaction}

\begin{tabular}{|c|c|c|c|c|c|}
\hline Constructs & $\mathrm{CR}$ & AVE & MSV & ASV & \\
\hline $\begin{array}{l}\text { Job satisfaction(Intrinsic) } \\
\text { Job satisfaction(Extrinsic) }\end{array}$ & 0.908 & 0.622 & 0.010 & 0.005 & \\
\hline Job satisfaction(Extrinsic) & 0.840 & 0.513 & 0.010 & 0.005 & Table 7. \\
\hline \multicolumn{5}{|c|}{$\begin{array}{l}\text { Note: The table gives the results for convergent validity and discriminant validity with the help of } \\
\text { confirmatory factor analysis(CFA) on Amos } 21 \text { platform } \\
\text { Source: Computed by researcher }\end{array}$} & $\begin{array}{l}\text { Values showing the } \\
\text { validity for job } \\
\text { satisfaction scale }\end{array}$ \\
\hline
\end{tabular}


Figure 2.

Structural model of relationship between BoS and job satisfaction

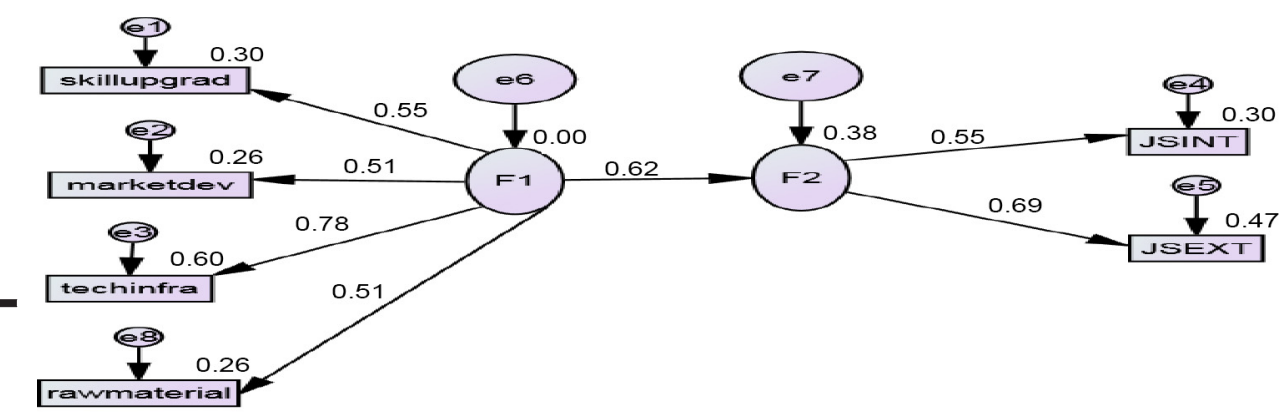

Notes: The figure shows the relationship between the BoS and job satisfaction. Here the BoS significantly predicts the job satisfaction among the handloom weavers, i.e. the predictor variable (here BoS) explains $38 \%$ of variance in job satisfaction

Table 8.

Values of model fit as obtained from structural equation modeling

\begin{tabular}{lcccccr}
\hline CMIN & CMIN/DF & GFI & AGFI & NFI & RMSEA & CFI \\
\hline 11.192 & 1.339 & 0.989 & 0.971 & 0.908 & 0.035 & 0.970
\end{tabular}

Notes: All the values indicated a good fit of the model with $p<.001$. The table gives the values of Model fit as produced after using structural equation modeling method

Source: Computed by researcher

Table 9.

the Measure of standardized and un standardized regression weights, standard error and significance at significance level $p<0.001$. The value of $\mathrm{r}^{\wedge} 2$ was found to be 0.38 which was significant (Table 9), which means BoS significantly affects job satisfaction among handloom weavers who were the beneficiaries of the scheme.

\section{Findings}

The above model (Figure 2) concurs with the hypothesis that BoS significantly affects the job satisfaction among the handloom weavers. The null hypothesis holds true in the study undertaken, i.e. there is significant relationship between BoS and job satisfaction (Figure 1). The effects of the BoS on job satisfaction are still in a nascent stage. This evidential support

\begin{tabular}{lccccc}
\hline Parameter & Un standardized estimate & Standardized estimate & Standard error & C.R & P \\
\hline F2 $\leftarrow$ F1 & 0.531 & 0.618 & 0.088 & 6.046 & $* * * *$ \\
SUS $\leftarrow$ F 1 & 0.794 & 0.552 & 0.106 & 7.486 & $* * *$ \\
MDS $\leftarrow$ F1 & 0.862 & 0.507 & 0.119 & 7.251 & $* * *$ \\
TIS $\leftarrow$ F1 & 1.000 & 0.775 & & & \\
JS(Int) $\leftarrow$ F2 & 0.714 & 0.547 & 0.140 & 5.097 & $* * *$ \\
JS(Ext) $\leftarrow$ F2 & 1.000 & 0.688 & & & \\
RMS $\leftarrow$ F2 & 1.068 & 0.512 & 0.146 & 7.298 & $* * *$
\end{tabular}

Notes: F1 here refers to benefits of the scheme. F2 refers to job satisfaction. Significance level $p<0.001$. The table clearly depicts that BoS significantly affects job satisfaction

Source: Computed by researcher 
work can clear a path for additional work in this area. The measure of $\mathrm{r}^{\wedge} 2$ was found to 0.38 which means that the antecedent (BoS here) explains 38\% of variance in job satisfaction, which was found to be significant at $p<0.001$ (Table 9). The data was found to be reliable as reflected by the values of Cronbach's alpha. The exploratory factor analysis aggregated the factors which were in adherence with the literature (Tables 2-5). The KMO value for job satisfaction scale was found to be 0.763 and 0.659 for BoS scale. The confirmatory factor analysis helped to validate the psychometric properties of the measuring scales used, which gave evidential support for the convergent and discriminant validity of the measuring instruments in the given context (Tables 6 and 7).

\section{Conclusion}

The conducted work gave results which corroborate with the hypotheses of the existence of relationship between BoS and job satisfaction in the current context. The application of job satisfaction in labor economics (Freeman, 1977) and its relevance in quitting behavior of workers (Green, 2010) make it very important variable in the current context. The weavers because of several challenges often have been found to quit the job handloom weaving and take up other jobs. The reasons cited are many such as better wages, easy working environment and so on. Reasons for quitting behavior whether is because of other opportunities or not is different matter altogether, but if look at the results obtained, the schemes which have features which are work centric are playing a very important role in enhancing job satisfaction. The output of the study gets support from a work on Midwives in Nigeria where Midwifery Service Scheme in Nigeria helps in not only in enhancing job satisfaction but also retaining the midwives (Adegoke et al., 2015). The different strands of literature if put together point in the direction that the work-centric support of the schemes caters to both extrinsic and intrinsic facets of job satisfaction. This can be seen with regard to Herzberg's motivation - hygiene theory. The feelings related to work itself, such as recognition, advancement, etc., are classified under motivational factors, whereas feelings related to externalities of the job such as wages, working conditions are termed as hygiene factors (Herzberg, 1966). Study conducted in Ghana reported that there is positive effect of fair trade certification on job satisfaction. The Fair Trade certification which promotes job satisfaction by affecting both intrinsic and extrinsic benefits the workers in pineapple plantation in Ghana. The certification focuses on the aspect of working conditions, wages, safety measures and provided market to sell the produce and ensure stable price (Krumbiegel et al., 2018). Rural handloom clusters in Ethiopia which have shown better productivity by improved infrastructure in form of better lighting facilities. The development of clusters helps the weavers to become empowered and become visible entity. This promotes the overall development, as the clusters represent those geographical areas which specialize in particular designs/products. It gives them edge in terms of competitiveness and product diversification. The collectivization of clustering of weaving activity has given a boost to industrial development in Ethiopia (Zhang et al., 2011). The job satisfaction questionnaire used for the study was based on the intrinsic and extrinsic satisfaction. The infrastructure support is strong measure to bail out the possibility of dissatisfaction from working conditions. The skill up-gradation and marketing support activities are features of the scheme which can go well along with intrinsic job satisfaction by attaching a meaning and dignity to their work. The hygiene factors that contribute to the dissatisfaction is very well-countered by support in form of technical infrastructure support. The motivational factors which are intrinsic to the job are also being taken care of by the scheme. All schematic support aims at the betterment of livelihood of the weavers, which is achieved by increase in remuneration by assisting them to creating uniquely designed 
$\mathrm{XJM}$

$17,1 / 2$

124

products. The market creation provides platform for show casing their designs and also promotes awareness among people about handloom products. The comprehensive handloom cluster development supports the weavers with raw materials, skill up-gradation training, market development and infrastructure support for better working conditions. These features show significant effect on job satisfaction indicating a strong relationship between the two variables.

\section{Implications}

The study suggests that BoS can be strong predictor for job satisfaction. This evidential support can be a useful tool for the policymakers to further strengthen the features of the scheme. They should work in direction of inclusion of more handloom weavers in the framework of the scheme. The Job satisfaction is a positive component of work-related wellbeing (Rothmann, 2008), so an increase in job satisfaction would lead to better work-related well-being. Similar type of study can be replicated in other countries too where the artisans are facing similar issues and the government is working in the direction for the protection and survival of that art form. Artisans (Songket weavers) in Malaysia face issues of dreadful working conditions such as dim light and lack of proper market (Kheng and Ngo, 2010). Handloom weavers in Sri Lanka also face challenges in terms of poor wages, difficulty in raw material procurement, lack of market information (Report of Task Force for a sustainable development of The Handloom Industry in Sri Lanka, 2012). Institutional bodies under the patronage of government in these countries are taking strong measures in the form of schemes/interventions to address these issues. Yayasan Tuanku Nur Zahirah is a foundation in Malaysia under the royal patronage of Malaysia (Kheng and Ngo, 2010), Department of Textile Industries-DTI, EDB - Export Development Board in Sri Lanka. Job satisfaction reduces labor mobility and enhances performance and workers well-being. Such studies can be a useful tool for analysis of the scheme under the ambit of job satisfaction and labor mobility. This might help in synthesis of ideas for better policy implementation and customization of policy benefits as per the specific needs of the workers. Similar approach can be applied to study about job satisfaction among other unorganized sectors where the government plays a crucial role in the sustenance. The study suggests a technique to study about the government schemes in the light of the outcomes or intended benefits. This sort of examination of the schemes can help in reasonable need based modifications of the schemes so as to give more privilege to the beneficiaries.

\section{Contribution}

Job satisfaction is already a well-established variable for labor economics for analyzing labor mobility. The present study tries to join the strands of job satisfaction with benefits of scheme. The study is also suggestive of a method to study schemes in the light of the benefits/features that it intends to deliver. There have been wide literature support for schemes enhancing well-being among the beneficiaries. The women residing in public housing have better well-being than the ones living in slum houses (Vaid, 2013).This particular study can carve a pathway to explore relational evidences for job satisfaction and schemes for an obvious reason that work forms an important facet for well-being of an individual. The work centric schemes by enhancing job satisfaction can enhance workrelated well-being which in turn would develop overall well-being of the individuals. The study can be a precursor for further research on the effects of schemes on work-related wellbeing. The components of work-related well-being are job satisfaction, occupational stress, burn out and work engagement (Rothmann, 2008). 


\section{References}

Adams, J.S. (1965), "Inequity in social exchange", in Berkowitz, L. (Ed.), Advances in Experimental and Social Psychology, Academic Press, New York, NY, pp. 276-299.

Adegoke, A.A., Atiyaye, F.B., Abubakar, A.S., Auta, A. and Aboda, A. (2015), "Job satisfaction and retention of midwives in rural Nigeria”, Midwifery, Vol. 31 No. 10, pp. 946-956.

Almeida, N.A.D.H. and Perera, G.D.N. (2015), "The impact of welfare on job satisfaction among non managerial employees in the apparel industry in Sri Lanka", 2nd International HRM Conference, Vol. 2.

Ayre, C. and Scally, A. (2014), “Critical values for lawshe's content validity ratio: revisiting the original methods of calculation”, Measurement and Evaluation in Counseling and Development, Vol. 47 No. 1, pp. 79-86.

Bernstein, D.A. and Nash, P.W. (2008), Essentials of Psychology, 4th ed., Cengage Learning, Boston, available at: http://books.google.com/books?id=4Do-bFrt9tUC

Byrne, B.M. (2013), Structural Equation Modeling with LISREL, PRELIS, and SIMPLIS: Basic Concepts, Applications, and Programming, Psychology Press.

Chaubey, D.S. and Rawat, B. (2016), "Analysis of labour welfare schemes and its impact on job satisfaction: an empirical study", Management Convergence, Vol. 7 No. 2, pp. 45-53.

Chen, C.F. (2008), "Investigating structural relationships between service quality, perceived value, satisfaction, and behavioral intentions for air passengers: evidence from Taiwan", Transportation Research Part A: Policy and Practice, Vol. 42 No. 4, pp. 709-717.

Clark, A.E. (2001), "What really matters in a job? Hedonic measurement using quit data", Labour Economics, Vol. 8 No. 2, pp. 223-242.

Cohen, A.B., Pierce, J.D., Chambers, J., Meade, R., Gorvine, B.J. and Koenig, H.G. (2005), "Intrinsic and extrinsic religiosity, belief in the afterlife, death anxiety, and life satisfaction in young catholics and protestants", Journal of Research in Personality, Vol. 39 No. 3, pp. 307-324, doi: 10.1016/j. jrp.2004.02.005.

Delhey, J. and Kohler, U. (2006), "From nationally bounded to pan-European inequalities? On the importance of foreign countries as reference groups", European Sociological Review, Vol. 22 No. 2, pp. 125-140.

Fasang, A.E., Geerdes, S. and Schömann, K. (2012), "Which type of job mobility makes people happy? A comparative analysis of European welfare regimes", International Sociology, Vol. 27 No. 3, pp. 349-383.

Freeman, R.B. (1977), "Job satisfaction as an economic variable (no. w0225)", National Bureau of Economic Research.

Goswami, R. and Jain, R. (2014), "Strategy for sustainable development of handloom industry”, Global Journal of Finance and Management, Vol. 6 No. 2, pp. 93-98.

Green, F. (2010), "Well-being, job satisfaction and labour mobility", Labour Economics, Vol. 17 No. 6, pp. 897-903.

Hackman, J.R. and Oldham, G.R. (1976), "Motivation through the design of work: test of a theory", Organizational Behavior and Human Performance, Vol. 16 No. 2, pp. 250-279.

Hamermesh, D. (2001), "The changing distribution of job satisfaction", The Journal of Human Resources, Vol. 36 No. 1, pp. 1-30, doi: 10.2307/3069668.

Heins, E. and Deeming, C. (2015), "Welfare and well-being-inextricably linked", Defence of Welfare, Vol. 2, p. 13.

Helliwell, J., Layard, R. and Sachs, J. (2012), World Happiness Report, United Nations, New York.

Heppner, P.P., Wampold, B.E., Owen, J., Wang, K.T. and Thompson, M.N. (2016), Research Design in Counseling, 4th ed., Cengage Learning, Boston.

Herzberg, F.I. (1966), Work and the Nature of Man, World. 
$\mathrm{XJM}$

$17,1 / 2$

Hirschfeld, R.R. (2000), "Validity studies. Does revising the intrinsic and extrinsic subscales of the Minnesota satisfaction questionnaire short form make a difference?", Educational and Psychological Measurement, Vol. 60 No. 2, pp. 255-270.

Judge, T.A. and Church, A.H. (2000), "Job satisfaction: research and practice", in Cooper, C.L. and Locke, E.A. (Eds), Industrial and Organizational Psychology: Linking Theory with Practice, Blackwell, Oxford, pp. 166-198.

Kheng, J.N.S. and Ngo, J. (2010), "Sustaining the magnificent craft of songket weaving in Malaysia", Proceedings of the 12th Biennial Textile Society of America Symposium, pp. 1-12.

Krumbiegel, K., Maertens, M. and Wollni, M. (2018), "The role of fairtrade certification for wages and job satisfaction of plantation workers", World Development, Vol. 102, pp. 195-212.

Lawshe, C.H. (1975), “A quantitative approach to content validity”, Personnel Psychology, Vol. 28 No. 4, pp. 563-575.

Lévy-Garboua, L., Montmarquette, C. and Simonnet, V. (2007), "Job satisfaction and quits", Labour Economics, Vol. 14 No. 2, pp. 251-268.

Locke, E.A. (1976), “The nature and causes of job satisfaction”, in Dunnette, M.D. (Ed.), Handbook of Industrial and Organizational Psychology, Rand McNally, Chicago, IL, pp. 1297-1349.

MacCallum, R.C., Browne, M.W. and Sugawara, H.M. (1996), "Power analysis and determination of sample size for covariance structure modeling”, Psychological Methods, Vol. 1 No. 2, p. 130.

Madanchian, M., Hussein, N., Noordin, F. and Taherdoost, H. (2018), "The impact of ethical leadership on leadership effectiveness among SMEs in Malaysia", Procedia Manufacturing, Vol. 22, pp. 968-974.

Maslow, A.H. (1943), “A theory of human motivation”, Psychological Review, Vol. 50 No. 4, pp. 370-396.

Meemken, E.M., Sellare, J., Kouame, C.N. and Qaim, M. (2019), "Effects of fairtrade on the livelihoods of poor rural workers", Nature Sustainability, Vol. 2 No. 7, pp. 635-642.

Mueller, C.W. and Kim, S.W. (2008), "The contented female worker: still a paradox?”, in Hegtvedt, K.A. and Clay-Warner, J. (Eds), Justice: Advances in Group Processes, Vol. 25, Emerald Group Publishing, Bingley, pp. 117-150, available at: http://books.google.com/books?id= rynLSn6zYRkC

Murphy, G. and Athanasou, J. (1999), "The effect of unemployment on mental health", Journal of Occupational and Organizational Psychology, Vol. 72 No. 1, pp. 83-99.

Nag, A., Vyas, H. and Nag, P.K. (2010), "Gender differences, work stressors and musculoskeletal disorders in weaving industries", Industrial Health, Vol. 48 No. 3, pp. 339-348.

Olubisi, A.T. (2018), "The effect of apprenticeship training on the performance of artisans: a case study of tailors in Ibadan North local government", Doctoral dissertation, Department Of Entrepreneurship, Faculty Of Management Science, National Open University Of Nigeria.

Origo, F. and Pagani, L. (2009), "Flexicurity and job satisfaction in Europe: the importance of perceived and actual job stability for well-being at work", Labour Economics, Vol. 16 No. 5, pp. 547-555.

Porter, L.W. and Lawler, E.E. (1968), Managerial Attitudes and Performances, Dorsey Press, Homewood, IL.

Ramswamy, R. and Kumar, N.J. (2013), "Women weavers in Mizoram: sustaining livelihood through cluster development”, Indian Journal of Gender Studies, Vol. 20 No. 3, pp. 435-452.

Rothmann, S. (2008), "Job satisfaction, occupational stress, burnout and work engagement as components of work-related wellbeing", SA Journal of Industrial Psychology, Vol. 34 No. 3, pp. 11-16.

Russell, J.A. (2003), "Core affect and the psychological construction of emotion", Psychological Review, Vol. 110 No. 1, pp. 145-172.

Rusticus, S. (2014), "Content validity", Encyclopedia of Quality of Life and Well-Being Research, Springer, Dordrecht, pp. 1261-1262. 
Sage, D. (2015), "Do active labour market policies promote the well-being, health and social capital of the unemployed? Evidence from the UK", Social Indicators Research, Vol. 124 No. 2, pp. 319-337.

Shrotryia, V.K. and Dhanda, U. (2019), "Content validity of assessment instrument for employee engagement”, Sage Open, Vol. 9 No. 1.

Soleimani, M.A., Yaghoobzadeh, A., Bahrami, N., Sharif, S.P. and Sharif Nia, H. (2016), "Psychometric evaluation of the Persian version of the templer's death anxiety scale in cancer patients", Death Studies, Vol. 40 No. 9, pp. 547-557.

Tanusree, S. (2015), "A study of the present situation of the traditional handloom weavers of Varanasi, Uttar Pradesh, India”, International Research Journal of Social Sciences, Vol. 4 No. 3, pp. 48-53.

Vaid, U. (2013), "Housing quality and well-being: evaluation of slum rehabilitation policy", dissertation or thesis, Cornell University.

Vroom, V.H. (1964), Work and Motivation, Wiley, New York, NY.

Warr, P. (1990), "The measurement of well-being and other aspects of mental health", Journal of Occupational Psychology, Vol. 63 No. 3, pp. 193-210.

Warr, P. (2007), Work, Happiness, and Unhappiness, Lawrence Erlbaum Associates, London.

Weiss, D.J., Dawis, R.V., England, G.W. and Lofquist, L.H. (1967), Manual for the MN Satisfaction Questionnaire: MN Studies in Vocational Rehabilitation, Minneapolis: Industrial Relations Center, University of MN.

Westover, J.H. (2012), "Comparative welfare state impacts on work quality and job satisfaction: a cross-national analysis", International Journal of Social Economics, Vol. 39 No. 7, pp. 503-525.

Wood, J.M. (2014), “Weavers unravelled: comparing associationalism among handloom weavers and boatmen in Varanasi, India”, South Asia: Journal of South Asian Studies, Vol. 37 No. 1, pp. $43-59$.

Zhang, X., Moorman, L. and Ayele, G. (2011), "Infrastructure and cluster development: a case study of handloom weavers in rural Ethiopia”, Journal of Development Studies, Vol. 47 No. 12, pp. 1869-1886.

\section{Further readings}

Dewanganla, K.N. and Sora2b, K. (2015), “Job demand and human-machine characteristics on musculoskeletal pain among female weavers in India”, Proceedings 19th Triennial Congress of the IEA, Vol. 9, p. 14.

Forgeard, M.J., Jayawickreme, E., Kern, M.L. and Seligman, M.E. (2011), "Doing the right thing: measuring wellbeing for public policy", International Journal of Wellbeing, Vol. 1 No. 1.

Hackman, J.R. and Oldham, G.R. (1980), Work Redesign, Addison-Wesley, Reading, MA.

Herzberg, F. (1968), “One more time: how do you motivate employees?”, Harvard Business Review, pp. $52-62$.

Herzberg, F., Mausner, B. and Snyderman, B. (1959), The Motivation to Work, John Wiley, New York, NY.

Hooper, D., Coughlan, J. and Mullen, M.R. (2008), "Structural equation modelling: guidelines for determining model fit", Electron J Bus Res Methods, Vol. 6, pp. 53-60.

Jha, J.K., Pandey, J. and Varkkey, B. (2019), "Examining the role of perceived investment in employees' development on work-engagement of liquid knowledge workers", Journal of Global Operations and Strategic Sourcing, Vol. 12 No. 2.

Vroom, V.H. (1995), Work and Motivation, 2nd ed., Wiley, New York, NY. 
$\mathrm{XJM}$

$17,1 / 2$

Wilson, F.R., Pan, W. and Schumsky, D.A. (2012), "Recalculation of the critical values for Lawshe's content validity ratio", Measurement and Evaluation in Counseling and Development, Vol. 45 No. 3, pp. 197-210.

\section{Reports}

Report by Government of India (2015), "Ministry of Textiles Note on Handloom Sector”, Dec 2015.

Report of GoI (2017), Ministry of Textiles Office of the Development Commissioner for Handlooms, May 2017.

Report of Task Force for a sustainable development of The Handloom Industry in Sri Lanka (2012), Report of the Task Force for a sustainable development of The Handloom Industry in Sri Lanka by Textile Industry Development Division Ministry of Industry and Commerce, January 2012.

Rural Development Lucknow (2016), Study Report on Problems and prospects of Handloom Sector by Bankers Institute od Rural Development Lucknow.

\section{Further reading}

Report by Asia Monitor Resource Center (2008), Home-Based Weavers in Varanasi Form a Union in The Struggle to Preserve Their Culture and Livelihood, Issue No. 66-67 January-June 2008.

\section{Corresponding author}

Sushmita Singh can be contacted at: sushmitasingh@fmsbhu.ac.in

For instructions on how to order reprints of this article, please visit our website: 